Research Paper

\title{
Modeling Business vs Non-Business Students Blended Learning Experience: Invariance Assessment and Multigroup Analysis
}

\section{Noraini Nasirun $^{1,2 *}$; Thurasamy Ramayah ${ }^{2,3,4}$; Shaiful Annuar Khalid ${ }^{1}$ and Shafiq Shahruddin ${ }^{1}$}

${ }^{I}$ Faculty of Business and Management, Universiti Teknologi MARA, Malaysia

${ }^{2}$ School of Management, Universiti Sains Malaysia, Malaysia

${ }^{3}$ Daffodil International University (DIU), Bangladesh, Malaysia

${ }^{4}$ Faculty of Economics and Business, Universiti Malaysia Sarawak (UNIMAS), Malaysia

*Corresponding author: noraininasirun@gmail.com

\begin{abstract}
Usually, business students perform better in entrepreneurship subjects as compared to non-business students. This study aims to compare performance between business and non-business students. Five variables (student engagement, student interactions, satisfaction, efficiency, and effectiveness) were included in the research framework as this study was underpinned by the Social Constructivism Approach. The study used a structured questionnaire to collect data from business students and nonbusiness students who were enrolled in the course Fundamental of Entrepreneurship. The data for the study was analyzed using SmartPLS 3.3.3. First, the invariance of measurement items was assessed using the Permutation analysis and then we ran a multigroup analysis to assess the measurement, structural model and group comparison. The results of this study reveal a significant difference between the positive direct effect between student interaction and effectiveness among business and non-business students. The results also show a significant difference between the indirect effect between student engagement and effectiveness among the compared groups. This study contributes to the literature within the spectrum of the Social Constructivism Approach. Moreover, the study outlines practical contributions to the higher learning institutions that use the online learning approach for large classrooms.
\end{abstract}

Keywords: Blended learning, Multigroup analysis, Entrepreneurship education, Student performance. 


\section{Introduction}

In recent times covid-19 pandemic has disrupted teaching and learning activities in higher education as most classes have shifted online. Likewise, many institutions are facing various challenges in conducting classes based on subjects or courses being offered. For instance, within the spectrum of entrepreneurship education, scholars agree that some knowledge and understanding of the entrepreneurial concepts come from core business classes as compared to the entrepreneurial classes (Liguori \& Winkler, 2020). During the pandemic, this issue is growing because of the restricted interactions between students, instructors, and also the infrastructure provided by the university (Ratten \& Jones, 2021). An emergency adoption of online learning is seen as one of the ways out to ensure classes can be conducted and the students' education is not affected (Patricia Aguilera-Hermida, 2020). Therefore, the need to study online learning including blended learning has become more important particularly to the institutions that have less infrastructure to support this type of learning.

Notably, comparison studies are one of the approaches scholars can employ in the study of entrepreneurship education. The majority of the extant studies compared two different concepts by exposing the learners to the content of the subject (PadillaAngulo, 2019), types of technology used in teaching and learning activities (Broadbent, 2017; Diep et al., 2017; Tarmuji et al., 2018), and previous experience related to the decision on their majoring (Newell et al., 1996). However, in the context of entrepreneurship education, few studies have compared the learning outcome between business and non-business students in one research context. A recent study by Paray and Kumar (2020) found that business students (management entrepreneurship) have a significantly higher entrepreneurial intention as compared to non-business students (science and technology) students.

This study is therefore underpinned by Social Constructivism Approach because it enhances learning through participation in learning activities in the learning environment (McMahon, 1997). Furthermore, scholars such as Bell and Bell (2020) suggested the social constructivism approach be included as the underpinning theory in the future research of entrepreneurship education. Student performance can be measured using several indicators, such as student satisfaction, effectiveness, and efficiency (Abuhassna et al., 2020; Mei et al., 2020). Over the past several years, the pattern of students' participation in online learning keep changing depending on various factors such as student engagement (Liu et al., 2020) and student interactions (Mei et al., 2020). A study by Hu et al., (2015) revealed that student interaction fully mediated the indirect relationship between student engagement and learning outcomes. Another study found that student interactions (student-faculty) mediated the relationship between class participation (student engagement through behavior) and learning outcome (Henrie et al., 2015).

Based on the above discussion, this study attempts to examine the differences in the direct effect of student engagement on student interactions, and student interactions towards learning outcomes (effectiveness, efficiency, and satisfaction) among business students and non-business students. It equally investigates the differences in the indirect student interactions as the mediator in the relationship between student engagement and learning outcome (effectiveness, efficiency, and satisfaction) among business students and non-business students who enrolled for the Fundamental of Entrepreneurship - 
ENT300. In this article, we present the pretesting, then the analysis using SmartPLS for the invariance assessment using permutation analysis and multigroup analysis for testing the differences in the relationships between the two groups and finally use PLSPredict to show predictive power and answer all the research objectives.

\section{Literature Review}

\section{Entrepreneurship Education}

Currently, entrepreneurship is one of the routes many countries use to stabilize their economy especially when the Covid-19 pandemic started in early 2020 (Maritz et al., 2020). The majority of the industries were badly affected, and the employment rate decreased tremendously. Scholars of entrepreneurship suggested that future researchers should focus more on components of entrepreneurship including entrepreneurship education (Ratten \& Jones, 2021; Secondo et al., 2021). With the restrictions of movement to contain the spread of Covid-19, the educators of entrepreneurship education must react quickly to the new way of doing business (Ratten, 2020; Secondo et al., 2021). An emergency online learning is one of the obstacles the higher institutions must face because the sudden decision of teaching and learning activities must be made with limited resources and infrastructures available (Ratten, 2020). One of the best ways to restructure online learning for entrepreneurship education is to take a few steps back and study the best practices of handling entrepreneurship education using blended learning or flipped classroom (Maritz et al., 2020; Noraini et al., 2020; Ratten \& Usmanij, 2021). From here, the institutions can formulate the best practices in blended learning to incorporate online learning for post-covid 19 eras.

\section{Development of the Research Framework}

\section{Social constructivism approach}

Social constructivism promotes learning in the learning environment itself (McMahon, 1997). McMahon (1997) further explains that students can participate in learning activities that are relevant to their learning environment. The learning environment may include the use of technology to facilitate experiential learning or even simulations. Social constructivism exists based on three main assumptions - reality, knowledge, and learning (B. Kim, 2010). Kim (2010) further explains that reality exists through human activities in society. It means that human activities in society promote the existence of creations. Additionally, knowledge is the output of the interactions among people in the society they live in. Finally, learning happens when people start to engage with these activities. Looking at these explanations, entrepreneurship education scholars suggested social constructivism approach be included as the underpinning theory in future research (Bell \& Bell, 2020). This is because the teaching and learning activities in entrepreneurship education shifted from traditional learning to online learning (Ratten \& Usmanij, 2021). Moreover, the teaching and learning activities in entrepreneurship education currently embedded in digital activities or classes have been conducted fully online (Secondo et al., 2021). 


\section{Student performance}

Student performance for this study consists of three variables, namely satisfaction, efficiency, and effectiveness. Blended learning scholars acknowledged satisfaction as one of the performance indicators in blended learning, where the majority of studies found that satisfaction levels are higher among students of blended learning as compared to traditional learning (Kuo et al., 2014). Similarly, in the context of emergency learning during Covid-19, these variables (satisfaction, efficiency, and effectiveness) are among the important indicators to measure learning outcomes (Abuhassna et al., 2020; Liu et al., 2020).

Satisfaction can be measured based on different conditions. One of the conditions is the platform or technology used to mediate the activities in blended learning. Among platforms that are commonly integrated are Learning Management System (LMS) (Kabassi et al., 2016), Facebook (Anthonysamy et al., 2020), WhatsApp (Noraini et al., 2020), and YouTube (Kim et al., 2014) in their online learning.

Efficiency in education refers to the use of minimum resources to produce the best outcome (Johnes et al., 2017; Liu et al., 2020). For instance, a study conducted by Chen et al. (2014) revealed that students are more efficient in blended learning using flipped classroom approach as the approach was beneficial to their learning.

Finally, effectiveness refers to the learning outcome such as new understanding or new knowledge a person acquires when experiencing a blended learning activity (Noesgaard \& Ørngreen, 2015). Effectiveness also had been highlighted as one of the important variables in the mainstream researches of blended learning (Drysdale et al., 2013; Halverson et al., 2014). Previous studies found that exposure to the experience may influence student intention. A study by Padilla-Angulo (2019) revealed that students who are exposed to entrepreneurship education increased their interest in entrepreneurial activities. Similarly, a study by Hassan et al., (2020) also found that business students engage more in entrepreneurship education as compared to nonbusiness students. Therefore, for this study, we attempt to investigate the differences between business students and non-business students for the measured variables, where business students were exposed more to the entrepreneurship contents as compared to non-business students. Thus, we hypothesize as follows:

H1 The positive effect of student interactions on effectiveness is stronger among business students compared to non-business students

H2 The positive effect of student interactions on efficiency is stronger among business students compared to non-business students

H3 The positive effect of student interactions on satisfaction is stronger among business students compared to non-business students

H4 The positive effect of student engagement on student interactions is stronger among business students compared to non-business students 


\section{Student interactions and student engagement}

Student interactions describe actions among individuals in the systems including individual interactions with other individuals, instructors, and content (Liu et al., 2020; Bernard et al., 2009). There are few studies that used student interactions as a mediator in the learning environment. Moreover, most of these studies focused only on studentfaculty interactions. A study by $\mathrm{Hu}$, Hung, Ching, $\mathrm{Hu}$, and Ching (2015) revealed that student interactions (student-faculty) fully mediated the indirect relationship between student engagement and learning outcomes. Another study found that student interactions (student-faculty) mediated the relationship between class participation (student engagement through behavior) and learning outcome (Henrie et al., 2015; Ko et al., 2016). Even though some studies did not clearly define student-faculty interaction, Meyer (2014) argued that instructors are also a representation of faculty in academic settings. Also, previous researchers suggested that team-based learning is suitable for large student groups with a small group of instructors (Morris, 2016). A comparison group study related to blended learning found that student interactions play an important role in the self-regulated learning environment, where those who interact more perform better in their study (Broadbent, 2017). Hence, for this study, we further investigate the indirect effect of student interactions as the mediator between student engagement and learning outcome (effectiveness, efficiency, and satisfaction). We hypothesize as follow:

H5 The positive indirect effect of student engagement on effectiveness is stronger among business students compared to non-business students

H6 The positive indirect effect of student engagement on efficiency is stronger among business students compared to non-business students

H7 The positive indirect effect of student engagement on satisfaction is stronger among business students compared to non-business students

\section{Methodology}

\section{Research Setting}

Universiti Teknologi MARA (UiTM) is one of the universities in Malaysia that focuses on the development of entrepreneurial activities among students. Fundamental of Entrepreneurship - ENT300 is the entrepreneurship subject offered at the diploma level. The syllabus and other control documents are prepared and disseminated by the Malaysian Academy of SME and Entrepreneurship Development (MASMED). In UiTM Perlis, 900 students enrolled every semester. Normally, 10 to 12 instructors are assigned to accommodate the teaching requirements. To achieve the standardization of the assessment, iCREATE was introduced in 2012. iCREATE is the instructional model to facilitate the teaching and learning activities for this subject. iCREATE integrates face-to-face and online activities through formal platforms (learning management system), and social media software such as WhatsApp and Facebook. Even though ENT300 is a university subject in UiTM, only UiTM Perlis used iCREATE as the instructional model for ENT300. Therefore, only UiTM Perlis ENT300 had experience with this environment. However, students who enrolled in this subject have wider 
access to the online content and support provided by the instructors and peers in the learning management systems from 33 branches of UiTM in Malaysia. These interactions allow students to explore and share knowledge beyond what can be offered by one branch campus. Furthermore, the interactions using social network software fosters the informal interactions as the support among peers related with clarification of the instructions such as the dateline of the report submission.

\section{Procedure of Data Collection}

Data collection was conducted two times in different semesters, (1) for the pilot study and (2) for the actual study. For the pilot study, data was collected using purposive sampling, while for the actual study, we used the systematic sampling technique. The sampling frame was derived from the student information system of the university. The inclusion characteristics of the respondents were, (1) students who enrolled for the subject of Fundamental of Entrepreneurship - ENT300 in the Universiti Teknologi MARA Perlis Branch, (2) undergone the blended learning instructional model (iCREATE) with $40 \%$ online interactions in their contact hour, (3) completed the summative assessments for the subject. The questionnaires were distributed in week 14 of the semester.

\section{Measurement Design}

The measurement for this study was adapted from previous scholars based on the operational definitions of the variables namely, satisfaction, efficiency, effectiveness, student interactions, and student engagement. The numbers of items and source of measurements are, (1) Satisfaction (5 items) adapted from Kuo et al. (2014), (2) Efficiency (4 items) adapted from Finstad (2010), (3) Efficiency (4 items) adapted from Finstad (2010), (4) Student Interactions (16 items) adapted from Kuo et al. (2014), and (5) Student Engagement (8 items) adapted from Dixson (2010) and Chen, Lambert, and Guidry (2010). They were measured using a 6-point Likert scale anchored by ' 1 ' as 'strongly disagree', '2' as 'disagree', ' 3 ' as somewhat disagree', '4' as somewhat agree', ' 5 ' as 'agree' and ' 6 ' as strongly agree. We chose a 6-point Likert scale to avoid the possibilities of response sets due to the odd scale, where respondents were confounded to a particular way of responses independently with the questions asked from the items (Lei Chang, 1994; Rennie, 1982).A total of 37 items were compiled for the measured variables. The study includes four demographic variables to capture the profile of the respondents.

\section{Ethical and Approvals}

For this study, we sought approvals from the authorities of UiTM, which consists of the Dean of Faculty of Business Management from UiTM Malaysia, the Assistant Rector (Academic Affair), head of entrepreneurship education, and the head of the learning center in UiTM Perlis Branch. 


\section{Pretesting}

\section{Cognitive aspects of survey methodology (CASM)}

The pretesting was conducted using Cognitive Aspects of Survey Methodology (CASM) to improve the content validity and pilot study to assess the measurement model for the research framework. The questionnaire was reviewed by eligible reviewers that include (1) the coordinator for ENT300 code in UiTM Perlis Branch, (2) two lecturers who were involved with the iCREATE instructional module teaching ENT300, and (3) five students who enrolled for ENT300 for the semester. The comments were recorded, and the questionnaires were amended accordingly. Besides the response process, the questionnaire was also reviewed by one professor and two senior lecturers to ensure the outline of the questionnaire, including the Likert scale is sufficient to achieve the assumptions for data analysis. At the end of CASM process, items for the measurement were revised and corrected based on reviews and comments from the reviewers.

\section{Pilot study}

The pilot study was considered as the first data collection for the overall study. Data was obtained in Week 14 of the semester. A total of 11 programs are offered by seven faculties in UiTM Perlis. The questionnaires were distributed to students based on the class list sorted by the program using purposive sampling. Ten questionnaires were targeted for each program. Out of 110 questionnaires distributed, only 105 were valid for further analysis. Data for the pilot study was analyzed using SmartPLS. The pilot study result exhibits that all item loadings were above 0.4 , composite reliability values were above 0.8 and AVE values were above 0.5 for reflective items. One item was deleted (D36) to improve the value of AVE. These results confirm that the items were valid for further analysis. Whereas for the formative model, the VIF value for all dimensions is below 3 , the paths are statistically significant and weight indicators are between -1 and +1 . These conditions confirm that the formative model achieved its convergence validity. Based on the pretesting, we concluded that the measurement was ready to be used for the actual study.

\section{Data Analysis}

Data analysis was conducted in several stages using SmartPLS 3. Firstly, we conducted a preliminary analysis that consists of normality tests as proposed by Cain and Zhang, (2016) and common method variance remedy, full collinearity estimates as suggested by Kock and Lynn (2012). Once the result was obtained, we conducted the assessment of the measurement results based on reporting suggested by Hair, Risher, Sarstedt, and Ringle (2019). Since the research model is a reflective-formative model, we analyzed data using a two-step approach. The result for the measurement model for the first-order construct (reflective) reports the value for items' loading, reliability value using composite reliability (CR), and convergent validity using average variance extracted (AVE). For the formative properties, we used the suggested reporting format by Xu et al., (2019) and for discriminant validity, we reported the HTMT indicators (Hair et al., 2019). Once the model achieved its reliability and validity, we tested the invariance assessment and multigroup (MGA) analysis of the research model using measurement invariance of composite models (MICOM) and multigroup analysis (MGA) as 
proposed by Cheah et al., (2020). Finally, the predictive power of the model was determined using PLSPredict (Shmueli et al., 2019).

\section{Results}

\section{Profile of the Respondents}

Two hundred and eighty-one respondents were involved in this actual study. The majority of the respondents were female $(71.2 \%)$ and male $(28.8 \%)$. The age group for those respondents was 20 years old $(73.7 \%), 21$ years old $(22.1 \%), 22$ years old $(3.2 \%)$, 23 years old (7\%), and 25 years old (4\%). The respondents represented by all programs in UiTM Perlis, namely AC110-Diploma in Accountancy (7.8\%), AC120-Diploma in Accounting Information System (4.3\%), AP120-Diploma in Geomatic Science (GIS) (6.8\%), AP122- Diploma in Geomatic Science (Natural Science) (4.6\%), AS115Diploma in Industrial Chemistry $(2.1 \%)$, AT110-Diploma in Planting Industrial Management (18.1\%), BM111-Diploma in Business Studies (8.5\%), BM119-Diploma in Banking (14.9\%), CS110-Diploma in Computer Science (9.6\%), CS143-Diploma in Quantitative Science (6.4\%), and SR113-Diploma in Sports Studies (16.7\%). Finally, business students constituted $35.6 \%$ while non-business was $64.4 \%$.

\section{Preliminary Analysis}

Normality and common method variance analysis were conducted in the preliminary stage. For the normality test, we used the skewness and kurtosis calculator provided by the https://webpower.psychstat.org/ (Cain et al., 2017). The result for skewness: $\beta=$ 10.791, or for kurtosis: $\beta=85.398$ indicates that the data was not normal. Therefore, the set of data was eligible to use SmartPLS as the option for data analysis. We investigated the common method bias of the measured variables using full collinearity estimates (Kock \& Lynn, 2012). The result (Table 1) indicates that the VIF values for measured variables were below 3.3, therefore free from the common method bias issue. See Table 1.

Table 1: Full Collinearity Estimates for the Study

\begin{tabular}{lccccc}
\hline Constructs & EFC & EFV & SAT & SE & SInt \\
\hline VIF & 2.885 & 2.417 & 1.903 & 2.375 & 3.095 \\
\hline
\end{tabular}

Note: EFC - Efficiency; EFV- Effectiveness; SAT-Satisfaction; SE - Student Engagement; SInt - Student Interactions

\section{Assessment of the Measurement Model}

The research model used for this study is a reflective-formative type. The first-order constructs are reflective (satisfaction, efficiency, effectiveness, student interactions, and student engagement), while the second-order constructs consisting of the dimension of student interactions is formative. Student interactions have three dimensions namely student-student, student-instructor, and student-content. Therefore, the measurement model was reported in two-step namely first-order construct (reflective) and the second- 
order construct (formative). For the result of the measurement model (reflective), we present the value for loading, reliability (composite reliability - CR), and convergent validity (average variance extracted - AVE) for business student and non-business student groups in Table 2.

Table 2 presents the assessment for the measurement model for first-order constructs (reflective). The assessment involved four variables namely satisfaction, efficiency, effectiveness, and student engagement. The cutoff value for loading acceptance was 0.60. As suggested by Hair et al., (2017), the indicators for outer loadings should be higher than 0.708 , however, loadings between 0.40 and 0.70 can be retained and valid for further analysis. For the business student group, only one item from student engagement (D31) shows loading below 0.70 with the loading value of 0.629 . Additionally, for the non-business student, only two items from student engagement constructs show loading below 0.7, namely D31 (0.699) and D38 (0.691). CR is the indicator to measure the reliability of the model and should be above 0.70 (Hair et al., 2019). Table 2 indicates that the CR values for all constructs for both groups are above 0.70 , hence the reliability of the constructs is achieved. Finally, the convergence validity is measured using AVE values. AVE minimum of 0.50 is preferred because it indicates that $50 \%$ of the variance is explained by the construct (Hair et al., 2019). Table 5 exhibits that AVE for all contracts for both groups is above 0.50 , hence, AVE for all constructs is acceptable for further analysis.

The discriminant validity for this model was measured using heterotrait-monotrait (HTMT) ratio, and the cut-off indicator value is 0.85 for constructs that are conceptually distinct. The cut-off value of 0.90 is applied to similar concepts (Hair et al., 2019; Henseler et al., 2014). In Table 4, only one HTMT indicator between efficiency and effectiveness for non-business groups reported a value of 0.892 , the rest of the indicators for both groups are below 0.85 . The constructs for efficiency and effectiveness represent a similar concept in the learning outcome (Drysdale et al., 2013), therefore the cut-off value of 0.90 can be applied. Thus, the HTMT indicators represented by both groups achieve the discriminant validity for both models and are valid for further analysis.

Conversely, the components of the convergent validity for the formative model are collinearity (VIF), statistical significance, and the weights of the dimensions (Hair et al., 2019; Xu et al., 2019). Table 3 presents that the VIF value for all dimensions is below 3 , the paths are statistically significant and weight indicators are between -1 and +1 . These conditions confirm that the formative model achieves its convergence validity, thus valid for further analysis.

\section{Assessment of the Structural Model and Multigroup Analysis (MGA)}

Once the research model for both groups already passed the robustness check using the assessment of the measurement models, a non-parametric structural equation modeling approach was applied to analyze the differences between business and non-business students using Henseler's MGA and the permutation test (Garson, 2016; Henseler et al., 2016). Before carrying out the multigroup analysis, the invariance assessment was tested using MICOM to ensure the heterogeneity of the groups (Henseler et al., 2016). The students are divided into two groups, namely business (100) and non-business (181) based on the faculty. MICOM using permutation consists of a three-step process: 
(1) the configurational invariance assessment, (2) the establishment of compositional invariance assessment, and (3) the assessment of equal means and variances. We ran a bootstrap of 5000 for the invariance measurement using a permutation test. The result presented in Table 5, suggested that the model established the partial invariance measurement for both groups (Garson, 2016; Henseler et al., 2016), hence further analysis for comparing and interpreting the MGA group-specific differences of PLSSEM can be performed.

Table 5 shows the results of the assessment of the structural model and MGA using both nonparametric methods: Henseler's MGA (Henseler et al., 2016) and the permutation test (Chin \& Dibbern, 2010). Henseler's MGA directly compares groupspecific bootstrap estimates from each bootstrap sample. According to this method, a p-value of differences between path coefficients lower than 0.05 or higher than 0.95 indicates a $5 \%$ level of significant differences between specific path coefficients across two groups (Henseler et al., 2009; Sarstedt et al., 2011). Four hypotheses were tested for direct effects (H1, H2, H3, and H4), and three indirect effects (H5, H6, and H7) were tested for this study.

In Table 6, using both Henseler's MGA and the permutation method, the results of MGA indicate significant differences for the direct effect of Student Interactions on Effectiveness across both groups with a p-value lower than 0.05 , hence hypothesis $\mathrm{H} 1$ is supported. The effect of Student Interactions on Effectiveness is higher for business students than non-business students. However, the results indicated no significant differences between other direct path coefficients and relationships across both groups, therefore other hypotheses tested for this study $(\mathrm{H} 2, \mathrm{H} 3$, and H4) cannot be supported based on the results. Later, hypotheses for indirect effects were tested. The results of Henseler's MGA and permutation method also indicate a significant difference for the indirect effect, whereby Student Interactions mediates the relationship between Student Engagement and Effectiveness across both groups with a p-value lower than 0.05. The effect of Student Interactions as the mediator between Student Engagement and Effectiveness is higher among business students as compared to non-business students Therefore, hypothesis H5 is supported. The results show no significant differences between other indirect path coefficients and relationships across both groups, therefore the other hypotheses tested for the indirect effect for this study (H6 and H7) were not supported.

\section{Predictive Model Assessment using PLSPredict}

PLSPredict is used to predict the power of model assessment tested in the study. We follow the steps suggested by Shmueli et al. (2019). Three endogenous constructs (Satisfaction, Efficiency, and Effectiveness) were involved in this test. Firstly, we assess the $\mathrm{Q}^{2}$ predict for the measurement variable and show that all values are above zero $\left(\mathrm{Q}^{2}\right.$ predict $\left.>0\right)$. Later we find the difference in the values between PLS-SEM-RMSEA against LM-RMSEA. In Table 7, the result indicates that all indicator values of PLSSEM < LM-RMSEA, hence this model has high predictive power, thus increasing the credibility of the overall results for this study. 
Table 2: Assessment Results of the Measurement Model (First-Order Construct - Reflective)

\begin{tabular}{|c|c|c|c|c|c|c|c|}
\hline \multirow{2}{*}{ Construct } & \multirow{2}{*}{ Item } & \multicolumn{2}{|c|}{ Loading } & \multicolumn{2}{|c|}{ CR } & \multicolumn{2}{|c|}{ AVE } \\
\hline & & Business & Non-Business & Business & Non-Business & Business & Non-Business \\
\hline \multirow[t]{5}{*}{ Satisfaction } & B11 & 0.782 & 0.759 & 0.892 & 0.882 & 0.623 & 0.600 \\
\hline & B12 & 0.837 & 0.846 & & & & \\
\hline & B13 & 0.747 & 0.828 & & & & \\
\hline & B14 & 0.784 & 0.710 & & & & \\
\hline & B15 & 0.793 & 0.719 & & & & \\
\hline \multirow[t]{4}{*}{ Efficiency } & B21 & 0.911 & 0.717 & 0.953 & 0.883 & 0.835 & 0.654 \\
\hline & $\mathrm{B} 22$ & 0.897 & 0.843 & & & & \\
\hline & B23 & 0.932 & 0.842 & & & & \\
\hline & B24 & 0.914 & 0.826 & & & & \\
\hline \multirow[t]{4}{*}{ Effectiveness } & B31 & 0.838 & 0.777 & 0.929 & 0.910 & 0.767 & 0.718 \\
\hline & B32 & 0.875 & 0.860 & & & & \\
\hline & B33 & 0.867 & 0.880 & & & & \\
\hline & B34 & 0.920 & 0.869 & & & & \\
\hline \multirow[t]{7}{*}{ Student Engagement } & D31 & 0.629 & 0.699 & 0.897 & 0.879 & 0.555 & 0.509 \\
\hline & D32 & 0.779 & 0.749 & & & & \\
\hline & D33 & 0.761 & 0.737 & & & & \\
\hline & D34 & 0.763 & 0.670 & & & & \\
\hline & D35 & 0.776 & 0.702 & & & & \\
\hline & D37 & 0.776 & 0.742 & & & & \\
\hline & D38 & 0.717 & 0.691 & & & & \\
\hline
\end{tabular}

Note: Item D36 (Student Engagement) has been deleted due to low loading 
Table 3: Assessment Results of the Measurement Model (Second-Order Construct - Formative)

\begin{tabular}{|c|c|c|c|c|c|c|c|}
\hline \multirow{2}{*}{ Construct } & \multirow{2}{*}{ Dimension } & \multicolumn{3}{|c|}{ Business } & \multicolumn{3}{|c|}{ Non-Business } \\
\hline & & Beta & t-value & VIF & Beta & t-value & VIF \\
\hline \multirow[t]{3}{*}{ Student Interactions } & Student-Content & 0.653 & $4.809 * *$ & 2.177 & 0.519 & $5.217 * *$ & 1.901 \\
\hline & Student-Instructor & 0.629 & $4.257 * *$ & 2.718 & 0.516 & $4.873 * *$ & 2.267 \\
\hline & Student-Student & 0.494 & $4.471 * *$ & 2.505 & 0.632 & $5.574 * *$ & 2.348 \\
\hline
\end{tabular}

Table 4: Discriminant Validity using HTMT

\begin{tabular}{|c|c|c|c|c|c|c|c|c|c|c|}
\hline & \multicolumn{5}{|c|}{ Business } & \multicolumn{5}{|c|}{ Non-Business } \\
\hline & $\mathbf{1}$ & 2 & 3 & 4 & 5 & 1 & 2 & 3 & 4 & 5 \\
\hline \multicolumn{11}{|l|}{ 1. Effectiveness } \\
\hline 2. Efficiency & 0.810 & & & & & 0.892 & & & & \\
\hline 3. Satisfaction & 0.744 & 0.570 & & & & 0.623 & 0.622 & & & \\
\hline 4. Std Engagement & 0.738 & 0.663 & 0.666 & & & 0.482 & 0.407 & 0.647 & & \\
\hline 5. Std Interactions & 0.788 & 0.657 & 0.710 & 0.858 & & 0.671 & 0.636 & 0.668 & 0.792 & \\
\hline
\end{tabular}


Table 5: Results of Invariance Measurement Testing using Permutation

\begin{tabular}{|c|c|c|c|c|c|c|c|c|c|c|c|}
\hline \multirow[t]{2}{*}{ Constructs } & \multirow[t]{2}{*}{$\begin{array}{l}\text { Configural } \\
\text { invariance } \\
\text { (Same } \\
\text { algorithms for } \\
\text { both groups) }\end{array}$} & \multicolumn{2}{|c|}{$\begin{array}{c}\text { Compositional } \\
\text { Invariance } \\
(\text { Correlation = 1) }\end{array}$} & \multirow[t]{2}{*}{$\begin{array}{l}\text { Permutation } \\
\text { p-value }\end{array}$} & \multirow[t]{2}{*}{$\begin{array}{c}\text { Partial } \\
\text { measurement } \\
\text { invariance } \\
\text { established }\end{array}$} & \multicolumn{2}{|c|}{ Equal mean value } & \multicolumn{2}{|c|}{ Equal variance } & \multirow[t]{2}{*}{$\begin{array}{l}\text { Permutation } \\
\text { p-value }\end{array}$} & \multirow[t]{2}{*}{$\begin{array}{c}\text { Full } \\
\text { measurement } \\
\text { invariance } \\
\text { established }\end{array}$} \\
\hline & & $\mathrm{C}=\mathbf{1}$ & $\begin{array}{c}\text { Confidence } \\
\text { Interval (Cis) }\end{array}$ & & & Differences & $\begin{array}{c}\text { Confidence } \\
\text { Interval (Cis) }\end{array}$ & Differences & $\begin{array}{c}\text { Confidence } \\
\text { Interval (Cis) }\end{array}$ & & \\
\hline Effectiveness & Yes & 0.999 & $\begin{array}{c}{[0.998,} \\
1.000]\end{array}$ & 0.387 & Yes & 0.003 & $\begin{array}{c}{[-0.215} \\
0.204]\end{array}$ & -0.019 & $\begin{array}{c}{[-0.328} \\
0.275]\end{array}$ & 0.158 & Yes \\
\hline Efficiency & Yes & 0.999 & $\begin{array}{c}{[0.996,} \\
1.000]\end{array}$ & 0.725 & Yes & 0.003 & $\begin{array}{c}{[-0.211} \\
0.201]\end{array}$ & -0.017 & $\begin{array}{c}{[-0.316} \\
0.285]\end{array}$ & 0.084 & Yes \\
\hline $\begin{array}{l}\text { Student } \\
\text { Interactions }\end{array}$ & Yes & 0.988 & $\begin{array}{c}{[0.963,} \\
1.000]\end{array}$ & 0.352 & Yes & 0.007 & $\begin{array}{c}{[-0.204} \\
0.209]\end{array}$ & -0.019 & $\begin{array}{c}{[-0.338} \\
0.300]\end{array}$ & 0.149 & Yes \\
\hline Satisfaction & Yes & 0.998 & $\begin{array}{c}{[0.995,} \\
1.000]\end{array}$ & 0.801 & Yes & 0.002 & $\begin{array}{c}{[-0.194,} \\
0.207]\end{array}$ & -0.008 & $\begin{array}{c}{[-0.345} \\
0.317]\end{array}$ & 0.107 & Yes \\
\hline $\begin{array}{l}\text { Student } \\
\text { Engagement }\end{array}$ & Yes & 0.998 & $\begin{array}{c}{[0.996,} \\
1.000]\end{array}$ & 0.909 & Yes & -0.003 & $\begin{array}{c}{[-0.212} \\
.0205]\end{array}$ & -0.003 & $\begin{array}{c}{[-0.296} \\
0.290]\end{array}$ & 0.039 & No \\
\hline
\end{tabular}

Note: Confidence Interval (CIs) $=[5 \%, 95 \%]$ 
Table 6: Results of Hypothesis Testing

\begin{tabular}{|c|c|c|c|c|c|c|c|c|c|}
\hline \multirow{2}{*}{ Нуро } & \multirow{2}{*}{ Relationships } & \multicolumn{2}{|c|}{ Path coefficient } & \multicolumn{2}{|c|}{ CIs (Bias corrected) $[5 \%, 95 \%]$} & \multirow{2}{*}{$\begin{array}{c}\text { Path coefficient } \\
\text { Differences }\end{array}$} & \multicolumn{2}{|c|}{ p-Value } & \multirow[b]{2}{*}{ Supported } \\
\hline & & Business & $\begin{array}{c}\text { Non- } \\
\text { Business }\end{array}$ & Business & Non-Business & & $\begin{array}{l}\text { Henseler's } \\
\text { MGA }\end{array}$ & $\begin{array}{c}\text { Permutation } \\
\text { test }\end{array}$ & \\
\hline H1 & $\begin{array}{l}\text { Student Interactions - } \\
>\text { Effectiveness }\end{array}$ & 0.739 & 0.605 & {$[0.633,0.801]$} & {$[0.510,0.680]$} & 0.135 & $0.033^{*}$ & $0.040^{*}$ & Yes/Yes \\
\hline $\mathrm{H} 2$ & $\begin{array}{l}\text { Student Interactions - } \\
>\text { Efficiency }\end{array}$ & 0.644 & 0.553 & {$[0.477,0.724]$} & {$[0.433,0.629]$} & 0.091 & 0.159 & 0.196 & No/No \\
\hline $\mathrm{H} 3$ & $\begin{array}{l}\text { Student Interactions - } \\
>\text { Satisfaction }\end{array}$ & 0.636 & 0.596 & {$[0.497,0.726]$} & {$[0.499,0.675]$} & 0.041 & 0.307 & 0.367 & $\mathrm{No} / \mathrm{No}$ \\
\hline $\mathrm{H} 4$ & $\begin{array}{l}\text { Std Engagement -> } \\
\text { Student Interactions }\end{array}$ & 0.783 & 0.698 & {$[0.708,0.832]$} & {$[0.619,0.763]$} & 0.085 & 0.064 & 0.088 & No/No \\
\hline H5 & $\begin{array}{l}\text { Std Engagement -> } \\
\text { Student Interactions - } \\
>\text { Effectiveness }\end{array}$ & 0.579 & 0.422 & {$[0.447,0.648]$} & {$[0.344,0.498]$} & 0.157 & $0.015^{*}$ & $0.022 *$ & Yes/Yes \\
\hline H6 & $\begin{array}{l}\text { Std Engagement -> } \\
\text { Student Interactions - } \\
>\text { Efficiency }\end{array}$ & 0.504 & 0.386 & {$[0.358,0.602]$} & {$[0.311,0.452]$} & 0.118 & 0.073 & 0.075 & No/No \\
\hline $\mathrm{H} 7$ & $\begin{array}{l}\text { Std Engagement -> } \\
\text { Student Interactions - } \\
>\text { Satisfaction }\end{array}$ & 0.498 & 0.416 & {$[0.363,0.579]$} & {$[0.334,0.497]$} & 0.082 & 0.156 & 0.184 & No/No \\
\hline
\end{tabular}

Note: $* \mathrm{p}<0.05$ 
Table 7: PLSPredict Assessment for Manifest Variables (Business and Non-Business)

\begin{tabular}{|c|c|c|c|c|c|c|c|c|c|}
\hline \multirow{3}{*}{ Constructs } & \multirow{3}{*}{ Items } & \multicolumn{4}{|c|}{ Business } & \multicolumn{4}{|c|}{ Non-Business } \\
\hline & & \multicolumn{2}{|c|}{ PLS } & \multirow{2}{*}{$\begin{array}{c}\text { LM } \\
\text { RMSE }\end{array}$} & \multirow{2}{*}{$\begin{array}{c}\text { RMSE } \\
\text { Difference } \\
\text { (PLS-LM) }\end{array}$} & \multicolumn{2}{|c|}{ PLS } & \multirow{2}{*}{$\begin{array}{c}\text { LM } \\
\text { RMSE }\end{array}$} & \multirow{2}{*}{$\begin{array}{c}\text { RMSE } \\
\text { Difference } \\
\text { (PLS-LM) }\end{array}$} \\
\hline & & RMSE & $\mathbf{Q}^{2}$ predict & & & RMSE & $\mathbf{Q}^{2}$ predict & & \\
\hline \multirow[t]{5}{*}{ Satisfaction } & B11 & 0.637 & 0.149 & 0.677 & -0.040 & 0.794 & 0.116 & 0.817 & -0.023 \\
\hline & B12 & 0.691 & 0.112 & 0.724 & -0.033 & 0.729 & 0.136 & 0.757 & -0.028 \\
\hline & B13 & 0.661 & 0.145 & 0.697 & -0.036 & 0.671 & 0.149 & 0.683 & -0.012 \\
\hline & B14 & 0.617 & 0.274 & 0.659 & -0.042 & 0.723 & 0.101 & 0.745 & -0.022 \\
\hline & B15 & 0.541 & 0.257 & 0.576 & -0.035 & 0.712 & 0.127 & 0.731 & -0.019 \\
\hline \multirow[t]{4}{*}{ Efficiency } & B21 & 0.555 & 0.314 & 0.585 & -0.030 & 0.657 & 0.158 & 0.672 & -0.015 \\
\hline & B22 & 0.531 & 0.339 & 0.531 & 0.000 & 0.644 & 0.198 & 0.657 & -0.013 \\
\hline & $\mathrm{B} 23$ & 0.536 & 0.266 & 0.574 & -0.038 & 0.664 & 0.131 & 0.686 & -0.022 \\
\hline & B24 & 0.535 & 0.226 & 0.539 & -0.004 & 0.671 & 0.209 & 0.693 & -0.022 \\
\hline \multirow[t]{4}{*}{ Effectiveness } & B31 & 0.533 & 0.130 & 0.566 & -0.033 & 0.599 & 0.235 & 0.607 & -0.008 \\
\hline & B32 & 0.572 & 0.158 & 0.607 & -0.035 & 0.650 & 0.134 & 0.666 & -0.016 \\
\hline & B33 & 0.618 & 0.141 & 0.651 & -0.033 & 0.758 & 0.192 & 0.780 & -0.022 \\
\hline & B34 & 0.504 & 0.198 & 0.537 & -0.033 & 0.674 & 0.221 & 0.689 & -0.015 \\
\hline
\end{tabular}

Note: Item B11 to B15 - Satisfaction; Item B21 to B24 - Efficiency; Item B31 to B34 - Effectiveness 
Figure 1: Assessment of Measurement Model for Business Students

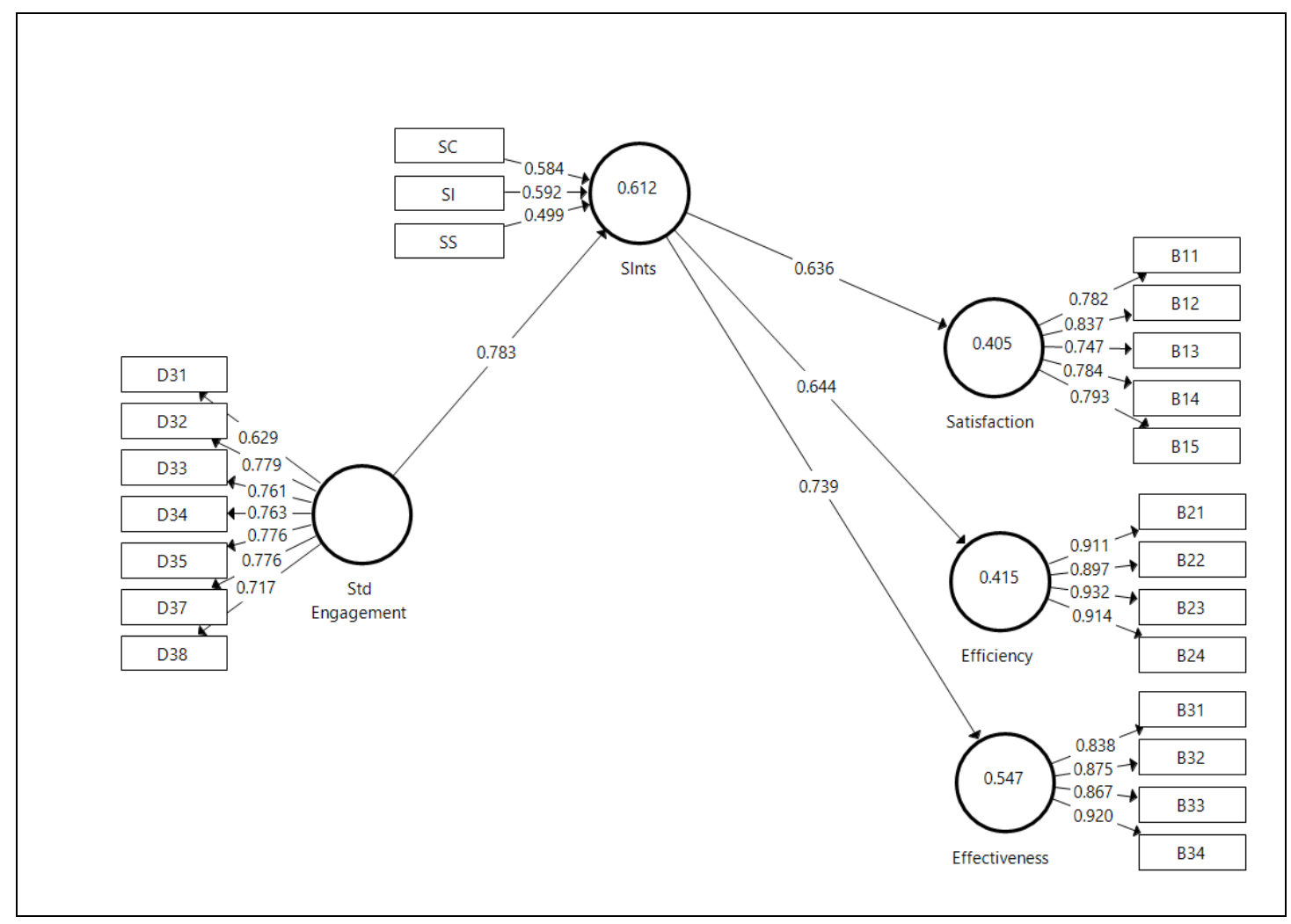

Figure 2: Assessment of Measurement Model for Non-Business Students

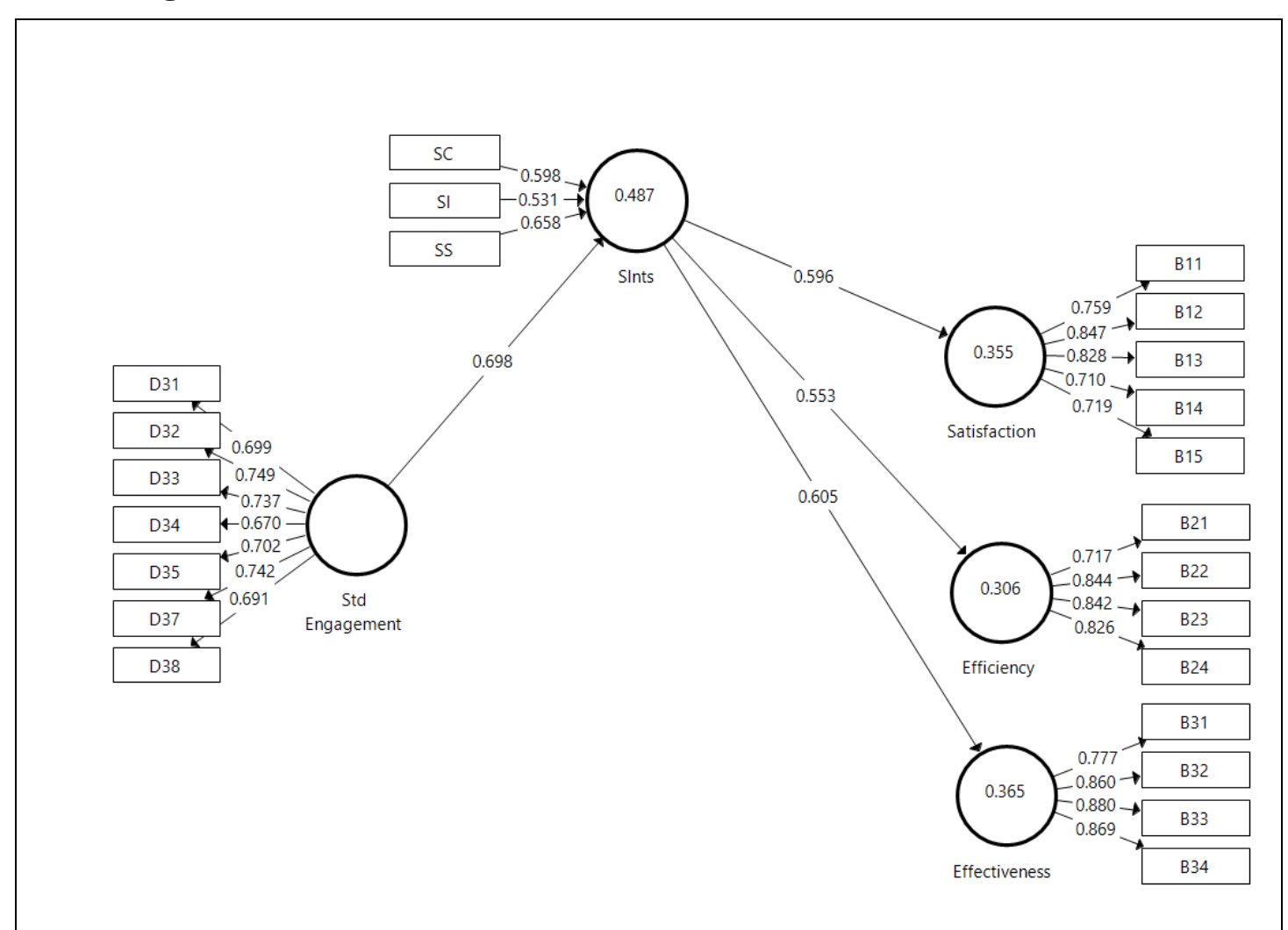

Note: SInts - Student Interactions 


\section{Discussion}

The Social Constructivism approach was applied in this study by looking at how students of ENT300 participated in learning activities with the use of technology to facilitate their learnings. For this study iCREATE was used to handle the assessments using flipped classroom. Social constructivism exists based on three main assumptions namely reality, knowledge, and learning (Kim, 2010). Reality exists when students participated in their activities to fulfill ENT300 assessments. When they were involved with the activities in class, they started to understand the content of entrepreneurship. Later, when students interacted with instructors, peers, and online content, they gained a better understanding of the content thus improving learning. At this stage, students can propose an innovative product as a basis to prepare their business plan. Students started to develop their knowledge and reasoning why an innovative idea is needed in business. Learning occurs when students complete and present a business plan as the final assessment. If students were not engaged and interactive in their activities in ENT300 class, they were not able to apply their understanding in their assessments to complete them on time.

The MGA results obtained for student interactions and effectiveness show a significant difference between business and non-business students. The significant difference between business students and non-business students can be seen based on the exposure of the content to the students. Business students were exposed more to the business content as compared to the non-business students. Moreover, the students who participated in the study were the final year students, indicating these business students were the senior, who had undergone the majority of the lesson plan of the business program. Whereas, non-business students were exposed less to this subject. The majority of non-business students were only exposed to the pre-requisite subjects related to business and management. A study by Padilla-Angulo (2019) found that exposure to entrepreneurship content will influence the entrepreneurial outcomes among students. A study by Man and Kian (2014) reported that students who engaged in blended learning experienced the feeling of belonging to the community, and can communicate with instructors in the online environment. Business students already have their society to support their learning. Similarly, previous blended learning scholars found that students who interact were able to rely on peer support for clarity regarding the contents and confirmation related to their problem even if the instructor was not online at a particular time (Wah et al. 2014). The finding also aligns with the suggestion made by Morris (2016) where team-based learning in a blended learning environment could be applied for large student groups with a small group of instructors.

The MGA results also show a significant difference between business and non-business students when student interactions are tested as the mediator between the relationship of student engagement and learning outcome (effectiveness, efficiency, and satisfaction). The results suggested that business students and non-business students engage differently with the presence of student interactions. Business students show higher engagement to the understanding of the subject with the presence of student interactions. Furthermore, results from the earlier study suggested that student interactions mediate the relationship between class participation and learning outcome (Ko et al., 2016), as class participation also represents the behavior dimension of student engagement (Henrie et al., 2015). 
Even though this study shows that only two out of seven hypotheses were supported, the result indicates that iCREATE is a successful instructional model to handle entrepreneurship education. iCREATE was introduced as a solution to achieve standardization in handling entrepreneurship education for high student enrollment and many instructors teaching this subject in one semester. ICREATE facilitates students to engage and interact regardless of their educational background. However, the experience of business students makes them engage, interact and understand more as compared to the non-business students.

\section{Implications for Asian Business}

This study attempts to investigate the differences between the factors influencing students' outcomes among business students and non-business students in entrepreneurship education in UiTM Perlis. For this study, the instructional model iCREATE was used to achieve the standardization of the assessments and only applied in UiTM Perlis. Five variables were tested in this study namely satisfaction, effectiveness, efficiency, student interactions, and student engagement. Satisfaction, effectiveness, and efficiency were categorized as student performance. Student interactions were tested as a mediator and student engagement was tested as a predictor of student interactions and variables of student performance. Seven hypotheses were tested in this study. Four of the hypotheses tested the direct effect between variables while three of the hypotheses were indirect effects where student interactions were tested as a mediator.

The result shows that only two out of seven hypotheses were supported namely (1) a significant difference between student engagement and effectiveness, and (2) a significant difference between student engagement and effectiveness when student interactions were tested as a mediator. These indicate that iCREATE was a successful instructional model because either the students are business or non-business, they are satisfied with their learning and able to complete their assessment in time. Moreover, iCREATE also promotes all students to engage and interact in their learning environment through activities planned for this subject.

This study contributes to the Social Constructivism Approach because the engagement and interactions of students through participation in their learning activities lead to satisfaction, effectiveness, and efficiency in entrepreneurship subjects in the context of higher learning institutions. Apart from that, this study also suggests the dimensions of student interactions (student-student interaction, student-instructor interaction, and student-content interaction) should be analyzed as a formative dimension. These dimensions must not be dropped or separated in the study related to the technologymediated learning environment.

Overall, this study shows that a comparative study is required for business and nonbusiness students, particularly in the era of post-pandemic Covid-19. During Covid-19, the employability rate around the globe is decreasing and entrepreneurship is seen as one of the ways to improve the economy especially among developing countries like Malaysia, Indonesia, and other Asian countries. Education background must not be seen as an obstacle to starting a business. Hence, entrepreneurship education can be a first step to expose younger generations to get involved in a business venture. Therefore, the 
syllabus and the instructional model of entrepreneurship education must be planned properly to ensure students not only perform in their entrepreneurship subject but are also interested to start a business when they graduate from higher institutions.

\section{References}

Abuhassna, H., Al-Rahmi, W. M., Yahya, N., Zakaria, M. A. Z. M., Kosnin, A. B., \& Darwish, M. (2020). Development of a new model on utilizing online learning platforms to improve students' academic achievements and satisfaction. International Journal of Educational Technology in Higher Education, 17(1), 1-23.

Anthonysamy, L., Koo, A. C., \& Hew, S. H. (2020). Self-regulated learning strategies and nonacademic outcomes in higher education blended learning environments: A one decade review. Education and Information Technologies, 25, 3677-3704

Bell, R., \& Bell, H. (2020). Applying educational theory to develop a framework to support the delivery of experiential entrepreneurship education. Journal of Small Business and Enterprise Development, 27(6), 987-1004. https://doi.org/10.1108/JSBED-01-20200012

Broadbent, J. (2017). Comparing online and blended learner's self-regulated learning strategies and academic performance. Internet and Higher Education, 33, 24-32. https://doi.org/10.1016/j.iheduc.2017.01.004

Cain, M. K., Zhang, Z., \& Yuan, K. H. (2016). Univariate and multivariate skewness and kurtosis for measuring nonnormality: Prevalence, influence and estimation. Behavior research methods, 49(5), 1716-1735.

Cheah, J. H., Thurasamy, R., Memon, M. A., Chuah, F., \& Ting, H. (2020). Multigroup analysis using smartpls: Step-by-step guidelines for business research. Asian Journal of Business Research, 10(3), I-XIX. https://doi.org/10.14707/ajbr.200087

Chen, P. S. D., Lambert, A. D., \& Guidry, K. R. (2010). Engaging online learners: The impact of web-based learning technology on college student engagement. Computers and Education, 54(4), 1222-1232. https://doi.org/10.1016/j.compedu.2009.11.008

Chen, Y., Wang, Y., \& Chen, N.-S. (2014). Is FLIP enough? Or should we use the FLIPPED model instead? Computers \& Education, 79, 16-27. https://doi.org/10.1016/j.compedu.2014.07.004

Chin, W. W., \& Dibbern, J. (2010). An introduction to a permutation based procedure for multigroup PLS analysis: Results of tests of differences on simulated data and a cross cultural analysis of the sourcing of information system services between Germany and the USA. In Handbook of partial least squares (pp. 171-193). Springer, Berlin, Heidelberg.

Diep, A. N., Zhu, C., Struyven, K., \& Blieck, Y. (2017). Who or what contributes to student satisfaction in different blended learning modalities? British Journal of Educational Technology, 48(2), 473-489. https://doi.org/10.1111/bjet.12431

Dixson, M. D. (2010). Creating effective student engagement in online courses: What do students find engaging? Journal of the Scholarship of Teaching and Learning, 10(2), $1-13$.

Drysdale, J. S., Graham, C. R., Spring, K. J., \& Halverson, L. R. (2013). An analysis of research trends in dissertations and theses studying blended learning. The Internet and Higher Education, 17, 90-100. https://doi.org/10.1016/j.iheduc.2012.11.003

Finstad, K. (2013). Response to commentaries on 'The usability metric for user experience'. Interacting with Computers, 25(4), 327-330.

Garson, G. D. (2016). Partial Least Square: Regression \& Structural Equation Models.

Hair Jr, J. F., Sarstedt, M., Ringle, C. M., \& Gudergan, S. P. (2017). Advanced issues in partial least squares structural equation modeling. SAGE Publications Inc. 
Hair, J. F., Risher, J. J., Sarstedt, M., \& Ringle, C. M. (2019). When to use and how to report the results of PLS-SEM. European Business Review, 31(1), 2-24. https://doi.org/10.1108/EBR-11-2018-0203

Halverson, L. R., Graham, C. R., Spring, K. J., Drysdale, J. S., \& Henrie, C. R. (2014). A thematic analysis of the most highly cited scholarship in the first decade of blended learning research. The Internet and Higher Education, 20, 20-34. https://doi.org/10.1016/j.iheduc.2013.09.004

Hassan, A., Saleem, I., Anwar, I., \& Hussain, S. A. (2020). Entrepreneurial intention of Indian university students: the role of opportunity recognition and entrepreneurship education. Education and Training, 62(7-8), 843-861. https://doi.org/10.1108/ET-02-2020-0033

Henrie, C. R., Halverson, L. R., \& Graham, C. R. (2015). Measuring student engagement in technology-mediated learning: A review. Computers \& Education, 90, 36-53. https://doi.org/10.1016/j.compedu.2015.09.005

Henseler, J., Ringle, C. M., \& Sarstedt, M. (2014). A new criterion for assessing discriminant validity in variance-based structural equation modeling. Journal of the Academy of Marketing Science, 43(1), 115-135. https://doi.org/10.1007/s11747-014-0403-8

Henseler, J., Ringle, C. M., \& Sarstedt, M. (2016). Testing measurement invariance of composites using partial least squares. International Marketing Review, 33(3), 405431. https://doi.org/10.1108/IMR-09-2014-0304

Henseler, J., Ringle, C. M., \& Sinkovics, R. R. (2009). The use of partial least squares path modeling in international marketing. Advances in International Marketing, 20, 277319. https://doi.org/10.1108/S1474-7979(2009)0000020014

Hu, Y.-L., Hung, C.-H., Ching, G. S., Hu, Y.-L., \& Ching, G. S. (2015). Student-faculty interaction: Mediating between student engagement factors and educational outcome gains. International Journal of Research Studies in Education, 4(1), 43-53. https://doi.org/10.5861/ijrse.2014.800

Johnes, J., Portela, M., \& Thanassoulis, E. (2017). Efficiency in education. Journal of the Operational Research Society, 68(4), 331-338. https://doi.org/10.1057/s41274-0160109-z

Kabassi, K., Dragonas, I., Ntouzevits, A., Pomonis, T., Papastathopoulos, G., \& Vozaitis, Y. (2016). Evaluating a learning management system for blended learning in Greek higher education. SpringerPlus, 5(1), 1-12.

Kim, B. (2010). Social constructivism. In M. Orey (Ed.), Emerging Perspectives on Learning, Teaching, and Technology (pp. 55-61). Jacobs Foundation.

Kim, M. K., Kim, S. M., Khera, O., \& Getman, J. (2014). The experience of three flipped classrooms in an urban university: an exploration of design principles. The Internet and Higher Education, 22, 37-50. https://doi.org/10.1016/j.iheduc.2014.04.003

Ko, J. W., Park, S., Yu, H. S., Kim, S.-J., \& Kim, D. M. (2016). The structural relationship between student engagement and learning outcomes in Korea. The Asia-Pacific Education Researcher, 25(1), 147-157. https://doi.org/10.1007/s40299-015-0245-2

Kock, N., \& Lynn, G. S. (2012). Lateral collinearity and misleading results in variance-based SEM: An illustration and recommendations. Journal of the Association for Information Systems Some, 13(7), 546-580. https://doi.org/10.1016/s0193-953x(18)30902-x

Kuo, Y.-C., Walker, A. E., Schroder, K. E. E., \& Belland, B. R. (2014). Interaction, Internet self-efficacy, and self-regulated learning as predictors of student satisfaction in online education courses. The Internet and Higher Education, 20, 35-50. https://doi.org/10.1016/j.iheduc.2013.10.001

Lei Chang. (1994). A psychometric evaluation of 4-Point and 6-Point Likert-type scales in relation to reliability and validity. Applied Psychological Measurement, 18(3), 205215. https://doi.org/10.1177/014662169401800302

Liguori, E., \& Winkler, C. (2020). From offline to online: Challenges and opportunities for entrepreneurship education following the COVID-19 pandemic. Entrepreneurship Education and Pedagogy, 3(4), 346-351. https://doi.org/10.1177/2515127420916738 
Liu, Z. Y., Lomovtseva, N., \& Korobeynikova, E. (2020). Online learning platforms: Reconstructing modern higher education. International Journal of Emerging Technologies in Learning, 15(13), 4-21. https://doi.org/10.3991/ijet.v15i13.14645

Man, C. K., \& Kian, S. H. (2014). Morpheus UNIMAS: Strenghthening student engagement in blended learning environemnt. In Blended \& Flipped Learning: Case Studies in Malaysian Higher Education Institutions (pp. 121-132). Bangi, Selangor: Centre for Teaching \& Learning Technologies UKM.

Maritz, A., Perenyi, A., de Waal, G., \& Buck, C. (2020). Entrepreneurship as the Unsung Hero during the Current COVID-19 Economic Crisis: Australian Perspectives. Sustainability, 12(11), 4612. doi:10.3390/su12114612

McMahon, M. (1997). Social constructivism and the World Wide Web - a paradigm for learning. What Works and Why : Reflections on Learning with Technology : ASCILITE, Imm, $1-7$. http://www.ascilite.org.au/conferences/perth97/papers/Mcmahon/Mcmahon.html

Mei, H., Lee, C. H., \& Xiang, Y. (2020). Entrepreneurship education and students' entrepreneurial intention in higher education. Education Sciences, 10(9), 1-18. https://doi.org/10.3390/educsci10090257

Meyer, K. A. (2014). Student engagement in online learning: What works and why. ASHE higher education report, 40(6), 1-114.

Morris, J. (2016). The use of team-based learning in a second year undergraduate preregistration nursing course on evidence-informed decision making. Nurse Education in Practice, 21, 23-28. https://doi.org/10.1016/j.nepr.2016.09.005

Newell, S. J., Titus, P. A., \& West, J. S. (1996). Investigating the Undergraduate Student Decison-Making Process for Selecting a Business Specialization: A Comparison of Markeitng and Nonmarketing Business Students. Journal of Marketing Education, 18(3), 57-67.

Noesgaard, S. S., \& Ørngreen, R. (2015). The effectiveness of e-learning: An explorative and integrative review of the definitions, methodologies and factors that promote eLearning effectiveness. Electronic Journal of E-Learning, 13(4), 278-290.

Noraini, N., Ramayah, T., \& Noor, S. M. (2020). Handling massive enrollment for achieving results: A flipped classroom approach. International Journal of Online Pedagogy and Course Design, 10(4), 45-58. https://doi.org/10.4018/IJOPCD.2020100104

Padilla-Angulo, L. (2019). Student associations and entrepreneurial intentions. Studies in Higher Education, 44(1), 45-58. https://doi.org/10.1080/03075079.2017.1336215

Paray, Z. A., \& Kumar, S. (2020). Does entrepreneurship education influence entrepreneurial intention among students in HEI's?: The role of age, gender and degree background. Journal of International Education in Business, 13(1), 55-72. https://doi.org/10.1108/JIEB-02-2019-0009

Aguilera-Hermida, A. P. (2020). College students' use and acceptance of emergency online learning due to COVID-19. International Journal of Educational Research Open, 1, 100011.

Ratten, V. (2020). Coronavirus (Covid-19) and the entrepreneurship education community. Journal of Enterprising Communities, 14(5), 753-764. https://doi.org/10.1108/JEC06-2020-0121

Ratten, V., \& Jones, P. (2021). Covid-19 and entrepreneurship education: Implications for advancing research and practice. International Journal of Management Education, 19(1), 100432. https://doi.org/10.1016/j.ijme.2020.100432

Ratten, V., \& Usmanij, P. (2021). Entrepreneurship education: Time for a change in research direction? International Journal of Management Education, 19(1), 100367. https://doi.org/10.1016/j.ijme.2020.100367

Rennie, L. J. (1982). Detecting a response set to Likert-style attitude items with the rating model. Education Research and Perspectives, 9(1), 114-118. http://www.rasch.org/erp9.htm/gifs/erp9.htm 
Sarstedt, M., Henseler, J., \& Ringle, C. M. (2011). Multigroup analysis in partial least squares (PLS) path modeling: Alternative methods and empirical results. In Measurement and research methods in international marketing (pp. 195-218). Emerald Group Publishing Limited.

Secundo, G., Gioconda, M. E. L. E., Del Vecchio, P., Gianluca, E. L. I. A., Margherita, A., \& Valentina, N. D. O. U. (2021). Threat or opportunity? A case study of digital-enabled redesign of entrepreneurship education in the COVID-19 emergency. Technological forecasting and social change, 166, 120565.

Shmueli, G., Hair, J. F., Ting, H., \& Ringle, C. M. (2019). Predictive model assessment in PLSSEM : guidelines for using PLSpredict. European Journal of Marketing, 52(11), 23222347. https://doi.org/10.1108/EJM-02-2019-0189

Tarmuji, N. H., Nassir, A. A., Ahmad, S., Abdullah, N. M., \& Idris, A. S. (2018). Students' acceptance of e-learning in mathematics: Comparison between LMS and MOOC using SEM PLS approach. AIP Conference Proceedings, 1974. https://doi.org/10.1063/1.5041708

Wah, L. K., Ing, N. S., Keaong, T. C., \& Jhee, Y. S. (2014). To flip or not to flip? finding from a Malaysian undergraduate course in UMS. In Blended \& Flipped Learning: Case Studies in Malaysian Higher Education Institutions (pp. 227-250). Bangi, Selangor: Centre for Teaching \& Learning Technologies UKM.

Xu, L., Peng, X., \& Prybutok, V. (2019). Formative measurements in operations management research: Using partial least squares. Quality Management Journal, 26(1), 18-31. https://doi.org/10.1080/10686967.2018.1542287 